Rev. Biol. Trop., 47(4): 1121-1127, 1999

www.ucr.ac.cr www.ots.ac.cr www.ots.duke.edu

\title{
Behavior and demography in an urban colony of Tadarida brasiliensis (Chiroptera: Molossidae) in Rosario, Argentina
}

\author{
Marcelo C. Romano, Juan I. Maidagan and Eduardo F. Pire.
}

Centro de Investigaciones en Biodiversidad y Ambiente (Ecosur), Pje. Sunchales 329, (2000) Rosario, Argentina. Fax: (54341) 4260177. E-mail: mromano@infovia.com.ar

Received 24- IX-1998. Corrected 7-IV-1999. Accepted 16-IV-1999.

\begin{abstract}
Bat colonies were sampled in the city of Rosario to increase the understanding of bat ecology in urban areas of the southern cone of South America. Seven species were recorded, of which three are new records for Rosario. One representative colony was chosen for intensive ecological study. Approximately 64000 Tadarida brasiliensis formed a maternity colony in the attic of an old building. Most of the bats were pregnant or lactating females and their young.. Adults arrive in the colony in mid-September and leave in February, no bats were present at this site from the beginning of March to mid-September. Births occur between mid-November and mid-December. Pups roosted in compact clusters in the nursery areas, spatially segregated from adults. Densities of these aggregations were $643 \pm 76$ bats $/ \mathrm{m} 2(\mathrm{p}<0.20)$. and adult densities were $161 \pm 21 \mathrm{bats} / \mathrm{m} 2(\mathrm{p}<0.20)$. 182 bats were captured. They were sexed and weighed. Mean adult females mass was, $13.26 \mathrm{~g}$ before parturition and $12.01 \mathrm{~g}$ after parturition. Recorded data included daily activity patterns.. Barn Owls (Tyto alba) and domestic cats prey on bats leaving the colony. Rabies virus was not detected. The insect biological control exerted by this colony was estimated and it would be of 209 to $385 \mathrm{~kg}$ of insects nightly between September and late February, demonstrating the important role they play in the urban ecosistem.
\end{abstract}

Key words: Argentina, bat biology, Tadarida brasiliensis, behavior, ecology, urban ecosystem, rabies.

Relatively recent studies have begun to shed light on the roles that bats play in various ecosystems, in aspects such as pollination, dispersal of propagules, control of insect populations, etc. (Estrada and Coates-Estrada 1993, Whitaker 1993, Iudica 1995, Tuttle 1988, Kunz et al. 1995 a, Valiente Banuet et al. 1996, McCracken 1996, Whitaker et al. 1996). This has begun to change attitudes towards bats, with the result that now many countries have specific legislation for their protection and that there are international treaties for the protection of migratory species (Anonymous 1981, Racey 1992, Anonymous 1994a, Anonymous 1994b).
Latin America has not yet reached this same level of protection. By comparison, there has been little systematic research on the biology and ecology of most neotropical species, and consequently a lack of information and public education campaigns on the crucial ecological roles played by many species of bats. This is further aggravated by the general belief that bats are dangerous animals, associated with diseases such as rabies (Constantine $\mathrm{et} \mathrm{al}$. 1968, Anonymous 1984, Tuttle 1985, Rosatte 1987, Fenton 1992, Bredt et al. 1996). This situation has led to the extermination of important bat populations, a common practice in 
rural areas throughout Latin America, and particularly in cities where both large and small colonies associated with buildings are systematically eliminated. The great majority of such colonies are composed of beneficial insectivores, fructivores, or polinivores, with the result that their persecution has highly negative consequences.

The purpose of this study was to sample and detect the presence of urban bat colonies, to chose one sufficiently representative from the point of view of size, location, degree of conflict, etc., and to conduct ecological studies of it to generate basic information on the dynamics of these mammals in an urban ecosystem, as a basis for future management decisions.

As a secondary aspect of this study, samples of bats were tested for the rabies virus. No cases of rabies have been detected in humans or domestic animals in Rosario for more than fifteen years. No systematic studies in wild animals have been done. Nevertheless, there is a latent concern about rabies, as it has been found in domestic animals and bats in regions close to the province of Santa Fe (Delpietro et al. 1972, 1987, De Diego and Valotta 1981).

The city of Rosario is within the distribution range of seven species of bats, four vespertilionids: Eptesicus diminutus, Eptesicus furinalis, Lasiurus cinereus, and Lasiurus ega, and three molossids: Tadarida brasiliensis, Eumops bonariensis, and Eumops patagonicus (Barquez et al. 1993).

\section{MATERIALS AND METHODS}

The study was conducted in the city of Rosario, Argentina, ( $32^{\circ} 57^{\prime} \mathrm{S}, 60^{\circ} 39^{\prime} \mathrm{W}$ ), $45 \mathrm{~m}$ above sea level. The climate is temperatesubtropical with a median annual temperature of $16.7^{\circ} \mathrm{C}\left(-8.8 / 41.9^{\circ} \mathrm{C}\right)$ and a mean annual precipitation of $1016 \mathrm{~mm}$, principally in the summer and autumn.

A survey was conducted between December of 1987 and February of 1988 in Rosario to locate bat colonies and select one for more detailed study. To locate colonies, people from various neighborhoods were asked whether there were bats in their area. Colonies detected in this way were visited, and the largest and most accessible (and thus possibly the one with the greatest potential for conflict) was selected for direct observation.

The selected colony inhabits the attic $(650$ $\mathrm{m}^{2}$ ) of the Law Faculty (National University of Rosario), built in 1888 and located downtown. This site was visited 60 times from 1988 to 1990 to observe, photograph, and sample the bats.

Various counting methods were analysed for determining the population size (Twente 1956, Humphrey 1971, Freeman et al. 1988, Fraze et al. 1990). Finally a photographic count method was designed and used to estimate the number of bats in the roost. Initial visits showed that the bats distributed themselves in two quite different areas: the "adult" area and the "nursery" area, with areas of 206 $\mathrm{m}^{2}$ and $49 \mathrm{~m}^{2}$ respectively. Paint was used to delineate a grid with $1-\mathrm{m}$ intervals. Two sets of 20 photographs were taken, the first between 30 September and 15 November 1989 (adult area) and the second between 30 November and 15 January 1990 (nursery area). The number of bats was determined from the photographs.

Stratified sampling (Caughley 1978) was used to estimate bat populations in the adult and nursery areas, strata A and B respectively. The samples included $17 \mathrm{~m}^{2}$ in stratum A and $6 \mathrm{~m}^{2}$ in stratum B. The mean population size and standard deviation were calculated for each area, and taking into account the total occupied roosting area, the total number of bats in the roost was calculated. An $80 \%$ reliability level was used according to the formula of Mood and Graybill (1978).

A metal box-trap designed for this purpose was used to capture bats in the roost. This trap had a 20-1 capacity, and a door activated by the weight of the bats. The trap was mounted on a 5-m long extensible handle allowing sampling of bats on the walls and ceiling of the attic. 
Sex, weight, and age class were determined for each captured bat, distinguishing "sub-adults" (those born during the season under study) from "adults" (those born before the season). Fur color and teeth sharpness were used to determine age class as suggested by Short (1961), with grey-colored individuals being sub-adults and red-brown individuals adults. In addition, 20 bat pups caught within 24 hours of birth were weighed and measured.

Day and night observations were recorded to establish behavior patterns. Times of departure and arrival of bats were recorded continuously at the attic entrance, and at hourly intervals within the roost.

A small number of samples for virological studies was taken. Briefly: i) 125 bats were anesthetized by ether, then their brain, subscapular fat and salivary glands were removed from each of them. A $10 \%$ suspension by mass was prepared and centrifuged for 5 minutes at 150-200 g, to remove tissue particles. The clear supernatant of each sample was mantained at $4{ }^{\circ} \mathrm{C}$ and then inoculated in a dose volume of $0.03 \mathrm{ml}$ by intracerebral route, according to the standard mouse inoculation test (Koprowski, 1996). The animals were checked daily, the number of mice found normal, sick or dead were recorded as a permanent record of the experiment.

ii) One hundred percent brain samples (125) were submited to fluorescent antibody tests, to detect rabies antigens in fresh specimen. Four smears of each brain sample were prepared. After mixing in acetone, they were stained with fluorescent rabies antibody conjugate produced at CePanZo (PHO/WHO), according to the technique described in Dean, et al. (1996).

iii) Simultaneously, rabies neutralizing antibodies were determined in serum samples from 32 individuals from the same colony using the standard procedures in mice blood samples (Delpietro, 1972) that were diluted 1: 4 in PBS sterile solution when blood samples were removed.

\section{RESULTS}

Seven species of bats were identified in various parts of the city based on preliminary surveys: Myotis levis, Lasiurus ega, Lasiurus borealis, Tadarida brasiliensis, Eumops patagonicus, Eumops bonariensis and Molossus molossus.

The attic of the building chosen was occupied by $\mathrm{T}$. brasiliensis and about $100 \mathrm{M}$. levis. Between September and February, most of the $\mathrm{T}$. brasiliensis were pregnant or lactating females and their young. No bats were present at this site from the beginning of March to sometime in September. The nursery area was unoccupied by adults until the onset of births. Parturition began in mid-November ( 9 and 10 in 1988; 12 and 13 in 1989) and lasted for about one month. Young were born naked and averaged $2.70 \mathrm{~g}, \pm 0.03 \mathrm{~g}(\mathrm{n}=20)$, with length of forearms averaging $18.01 \mathrm{~mm}, \pm 0.29 \mathrm{~mm}(\mathrm{n}$ $=20$ ). By five weeks of age, the bats began to take their first flights. The first females that gave birth roosted on the higher parts of the walls and successive bats in the lower areas. Young bats roosted in the nursery areas, but in response to disturbance, females moved their young to other parts of the building.

The adult $T$. brasiliensis population averaged $161 \pm 21$ bats $/ \mathrm{m}^{2}(\mathrm{p}<0.20)$, while young roosted in higher densities, $643 \pm 76$ bats $/ \mathrm{m}^{2}(\mathrm{p}$ $<0.20$ ). It is estimated that the total adult population in the colony was $33166 \pm 1001$, and $31507 \pm 1418$ in the nursery for a total population of $64673 \pm 1125 \mathrm{~T}$. brasiliensis.

A total of 182 bats (162 adults and subadults and 20 pups) were captured. The adult females captured in the roost averaged $13.26 \mathrm{~g}$, $\pm 0.13 \mathrm{~g}(\mathrm{n}=105)$ before parturition (October). Mean adult mass after parturition (January) was $12.01 \mathrm{~g}, \pm 0.15 \mathrm{~g}(\mathrm{n}=35)$. Sub-adults at 30 to 60 days of age averaged $11.09 \mathrm{~g}, \pm 0.18 \mathrm{~g}$ $(\mathrm{n}=10)$ for females, and $11.58 \mathrm{~g}, \pm 0.28 \mathrm{~g}(\mathrm{n}=$ 12) for males.

Roosting $\mathrm{T}$. brasiliensis adjusted their behavior according to weather conditions. On cooler days (temperatures $<23^{\circ} \mathrm{C}$ ), the bats 
were less active and tended to cluster together, while on very hot days (temperatures $>27^{\circ} \mathrm{C}$ ) the bats were more evenly distributed on the roost surface. On cloudy days the bats began to emerge from the colony 8-10 min earlier than on clear days.

In late October and early November (midSpring) the nightly patterns of departure from and return to the roost were as follows: during the first 10-15 minutes after approximately $2000 \mathrm{~h}$, small groups of five or six bats began to emerge, and over the next two hours the groups gradually increased in size until there was a massive flow of bats. By $2200 \mathrm{~h}$ the departure had stopped. The return started about $0245 \mathrm{~h}$ with small groups and increased until there was a massive flow of arriving bats. By $0530 \mathrm{~h}$ no bats were observed flying into the building. This pattern prevailed at all five attic entrances used by the bats.

Most bats were away from the roost for about five to six hours. Before the onset of parturition, all of the bats emerged. Afterwards, some adults remained in the nursery areas of the roost after the others had left.

Barn owls (Tyto alba) were always seen around the building, attacking emerging bats. Domestic cats also preyed on bats, typically catching those that had fallen to the ground.

In bats that were sampled for virological studies, neither rabies virus was isolated by the mice inoculation tests nor rabies antigens were detected by the FA tests. Rabies neutralizing antibodies were found in 5 to 32 bat sera (three adults females, two young males) at 1: 8 dilution.

\section{DISCUSSION}

Based on the species recorded in this study, and those previously cited for the region (Barquez et al., 1993), at least ten species had been recorded for the city of Rosario. The distribution areas reported by Barquez et al. (1993) suggest that other species may also be found in Rosario. A more detailed and specific study would be necessary to clarify local patterns of distribution.
The colony chosen for intensive study was composed mainly of $T$. brasiliensis, a species for which there are numerous reports on populations in the northern hemisphere (Twente 1956, Glass 1958, Short 1961, Davis et al. 1962, Villa et al. 1962, Herreid 1963, Constantine et al. 1968, Barbour et al. 1969, McCracken 1986, 1993, 1996, Freeman et al. 1988, Fraze et al. 1990, Balcombe \& McCracken 1992, Tuttle 1994, Kunz et al. 1995 a, 1995 b, Whitaker et al. 1996), but very little in the way of reports for South Americas.

Our general observations on the seasonal appearances of $T$. brasiliensis and its behaviour in the roost reflect those reported elsewhere in natural roosts (Twente 1956, Glass 1958, Davis et al. 1962, Villa 1962, Barbour and Davis 1969, Mc Cracken 1986, Wilkins 1989, Fraze and Wilkins 1990, McCracken \& Gustin 1991, Tuttle 1994, Kunz 1995 b) and in buildings (Krutzsch 1955, Licht and Leitner 1967).

There are numerous reports of predation on T. Brasiliensis colonies (Twente 1956, Glass 1958, Barbour and Davis 1969, Tuttle 1994), and our study corroborated these findings as various $T$. alba were observed living in the same building at the same time as the bats. This relation was studied in more detail (Romano et al. in prep.).

In recent years a growing number of studies have sought to deepen our understanding of interspecific ecological interactions, demonstrating the vital roles that many species of bats play in terrestrial ecosystems. Thus, when discussing the "management" of bat populations in urban ecosystems, it is important to balance the benefits provided by these bats against the risks they might represent for humans and domestic animals (Constantine 1970, Tuttle 1988).

Based on the relatively low incidence of rabies in the present study, they suggested a low risk of transmition from $T$. brasiliensis from this colony to the human population of Rosario.

Moreover if each adult $T$. brasiliensis consumed $50 \%$ to $100 \%$ (in nursing mothers) of 
its body mass in insects each night (Fenton 1983, McCracken \& Gustin 1987, Tuttle 1994, Kunz, et al. 1995 a), the bats in this colony would eat 209 to $385 \mathrm{~kg}$ of insects nightly between September and late February. These figures demonstrate the predation pressure exerted by $T$. brasiliensis on populations of nocturnal insects and their possible role in the biological control of some insects pests, just as it is documented in a recent report of McCracken (1996), this should help improve their public image.

\section{ACKNOWLEDGEMENTS}

The collaboration of Ana María Díaz and Alfonso Ruiz and the former Centro Panamericano de Zoonosis (PHO-WHO), Buenos Aires, was invaluable. We thank M.Brock Fenton, John Middleton, Patricia Torres, Virginia Serenelli and María E. Zaccagnini for their invaluable help, and the suggestions of three anonymous reviewers. Our research was supported in part, by a research grant from the Consejo de Investigaciones of the Universidad Nacional de Rosario, the Centro Panamericano de Zoonosis (PHO/WHO), and our personal funds.

\section{RESUMEN}

Con el objetivo de incrementar el conocimiento de la ecología de los murciélagos en áreas urbanas, se muestrearon colonias en la ciudad de Rosario. Fueron registradas siete especies, de las cuales tres son nuevos registros. Se seleccionó una colonia que se consideró más representativa, para realizar un intensivo estudio ecológico. Se realizaron conteos poblacionales, que arrojaron aproximadamente 64000 Tadarida brasiliensis formando una colonia maternal en el ático de un antigüo edificio. Se hicieron registros de comportamiento (fechas de arribo y partida, patrones diarios de actividad, pariciones, etc.). Los adultos arrivan al refugio a mediados de septiembre y lo abandonan en febrero. Las pariciones ocurren entre mediados de noviembre y mediados de diciembre. Las crías se ubicaron en grupos compactos en áreas separadas de los adultos, siendo su densidad de $643 \pm 76 / \mathrm{m}^{2}(p<$ $0.20)$. y la de los adultos de $161 \pm 21 / \mathrm{m}^{2}(p<0.20)$. 182 animales capturados fueron identificados, sexados y pe- sados. Los registros incluyeron patrones diarios de actividad.. Se detectó predación por "lechuza de campanario" (Tyto alba) y gatos domésticos. La búsqueda de virus rábico resultó negativa. Se estimó el control ejercido sobre poblaciones de insectos que, para esta colonia puede ser de 209 a $385 \mathrm{~kg}$ por noche entre septiembre y febrero, demostrando el importante rol que desempeñan en el ecosistema urbano.

\section{REFERENCES}

Anonymous 1994a. A Binational Partnership to Protect Mexican Free-tailed Bats. Bats 4: 6-7.

Anonymous 1994b. Acuerdo sobre la Conservación de Murciélagos en Europa. Convención sobre la Conservación de Especies Migratorias de Animales Silvestres (CMS), United Nations Environmental Program, Bonn, Germany.

Anonymous 1984. Séptimo informe Comité de Expertos sobre Rabia. Organización Mundial de la Salud, Servicio de información técnica 709, 104 p.

Anonymous 1981. Wildlife and Countryside Act, Sections 9-11, 16, 27 and 69. Nature Conservancy Council, London.

Atanasiu, P. 1966. Quantitative assay and potency test of antirabies serum. p. 167-172, In Anonymous (ed.). Laboratory Techniques in rabies 2 , Monograph Series 23, World Health Organization, Geneva.

Balcombe, J.P. \& G.F. McCracken. 1992. Vocal recognition in Mexican free-tailed bats: do pups recognize mothers?. Anim. Behav. 43: 79-87.

Barbour, R.W. \& W.H. Davis. 1969. Bats of America. The University of Kentucky, Lexington, 286 p.

Barquez, R.M., Giannini, N.P., Mares, M.A. 1993. Guide to the Bats of Argentina. Oklahoma Museum of Natural History, Oklahoma, 119 p.

Bredt, A. 1996. Morcegos e Saúde Pública. p. 24-36. In Bredt, A. (ed.). Morcegos em Áreas Urbanas e Rurais: Manual de Manejo e Controle. Fundaçào Nacional de Saúde, Brasília.

Caughley, G. 1977. Analysis of Vertebrate Populations. Wiley, New York, $234 \mathrm{p}$.

Constantine, D.G. 1970. Bats in relation to the health, welfare, and economy of man. p. 319-449, In W.A. Wimsatt (ed.). Biology of Bats, Vol. II. Academic, New York. 
Constantine, D.G. 1988. Health Precautions for Bat Researchers. p. 491-528. In T.H. Kunz (ed.). Ecological and Behavioral Methods for the Study of Bats. Smithsonian Institution, Washington D.C.

Constantine, D.G., E.S. Tierkel, M.D. Kleckner \& D.M. Hawkins. 1968. Rabies in New Mexico Cavern Bats. Public Health Reports 83: 303-316.

Davis, R.B., C.F.Herreid II \& H.L. Short. 1962. Mexican free-tailed bats in Texas. Ecol. Monogr. 32: 311-346.

Dean, D.H', M.K. Abelseth, P. Atanasiu. 1996. Chapter 7. In Anonymous (ed.). Laboratory techniques in rabies. World Health Organization, Geneva.

De Diego, A.I. \& J.R. Valotta. 1981. Virus Rábico en Murciélagos no Hematófagos. Situación en la República Argentina. Rev. Mil. de Vet. 29: 213-219.

Delpietro, H., A.M. Díaz, E. Fuenzalida \& J.F. Bell. 1972. Determinación de la tasa de ataque de rabia en murciélagos. Bol. Ofi. San. Panam. 63: 222-230.

Delpietro, H., F. Fabregas \& A.M. Díaz. 1987. Riesgo de transmisión rábica en la predación de quirópteros por carnívoros domésticos. Vet. Arg. 2: 748-756.

Estrada, A., Coates-Estrada, R. 1993. Bats and the Vanishing Rain Forests of Mexico. Bats 3: 6-11

Fenton, M.B. 1992. Bats Facts on file: New York. 212 p.

Fenton, M.B. 1983. Just bats. University of Toronto, Toronto, $165 \mathrm{p}$.

Fraze, R.K. \& K.T. Wilkins. 1990. Patterns of use of manmade roosts by Tadarida brasiliensis mexicana in Texas. Southwest. Nat. 35: 261-267.

Freeman, J. \& L. Wunder. 1988. Observations at a Colony of the Brazilian Free-tailed Bat (Tadarida brasilien sis) in Southern Colorado. Southwest. Nat. 33: 102 104.

Glass, B.P. 1958. Returns of Mexican freetail bats banded in Oklahoma. J. Mammal. 39: 435-437.

Herreid II, C.F. 1963. Temperature Regulation of Mexican Free-tailed Bats in Cave Habitats. J. Mammal. 44: 560-573.

Humphrey, S.R. 1971. Photographic estimation of population size of the Mexican free-tailed bat, Tadarida brasiliensis. Amer. Midl. Nat. 86: 220-223.
Iudica, C.A. 1995.Frugivoríaen Murciélagos: el frutero común (Sturnira lilium) en las Yungas de Jujuy, Argentina, p. 123-128. In Brown, A.D. y H.R.Grau (Eds.) Investigación, Conservación y Desarrollo en Selvas Subtropicales de Montaña. (Lab. de Inv. Ecol. de las Yungas, Tucumán, Argentina.

Koprowski, H. 1996. The mouse inoculation test, chapter 6. In Anonymous (ed.). Laboratory techniques in rabies. World Health Organization, Geneva.

Krutzsch, P.H. 1955. Observations on the Mexican freetailed bat, Tadarida mexicana. J. Mammal. 36: 236242.

Kunz, T·H., J.O. Whitaker Jr., M.D. Wadanoli 1995 (a). Dietary energetics of the insectivorous Mexican freetailed bat (Tadarida brasiliensis) during pregnancy and lactation. Oecologia 101: 407-415.

Kunz, T·H. \& S.K. Robson 1995 (b). Postnatal growth and development in the Mexican free-tailed bat (Tadarida brasiliensis mexicana): birth size, growth rates, and age estimation. J. Mammal. 76: 769-783.

Licht, P. \& P. Leitner. 1967. Behavioral responses to high temperatures in three species of Californiå bats. J. Mammal. 48: 52-61.

McCracken, G.F. 1996. Bats Aloft: A Study of HighAltitude Feeding. Bats 3: 7-10.

McCracken, G.F. 1993. Locational memory and femalepup reunions in Mexican free-tailed bat maternity colonies. Anim. Behav. 45: 811-813.

McCracken, G.F. 1986. Why Are We Losing Our Mexican Free-tailed Bats?. Bats 3: 1-4.

McCracken, G.F. \& M.K. Gustin. 1991. Nursing Behavior in Mexican Free-tailed Bat Maternity Colonies. Ethology 89: 305-321.

McCracken, G.F. \& M.K. Gustin. 1987. Batmom's Daily Nightmare. Nat. Hist. 10: 66-72.

Mood, A.M. \& F.A. Graybill. 1978. Introducción a la teoría de la estadística. Aguilar, Madrid, 536 p.

Racey, P.A. 1992. The Conservation of Bats in Europe. Bats 4: 4-10

Rosatte, R.C. 1987. Bat rabies in Canada: history, epidemiology and prevention. Can. Vet. J. 28: 754-756. 
Short, H.L. 1961. Age at sexual maturity of mexican freetailed bats. J. Mammal. 42: 533-536.

Tuttle, M.D. 1985. America's neighborhood bats. Univ. of Texas, Austin, $96 \mathrm{p}$.

Tuttle, M.D. 1988. The importance of bats. Bat Conservation International. Spec. Publ. 8 p.

Tuttle, M.D. 1994. The Lives of Mexican Free-tailed Bats. Bats 3: 6-14.

Tuttle, M.D. \& S.J. Kern. 1981. Bats and Public Health. Contributions in Biology and Geology; Milwaukee Public Museum 48: 1-11.

Twente, J.W. 1956. Ecological observations on a colony of Tadarida mexicana. J. Mammal. 37: 42-47.
Valiente-Banuet, A., Arizmendi, M.d.C., Rojas-Martínez. 1996. Nectar-Feeding Bats in the Columnar Cacti Forests of Central Mexico. Bats 2: 12-15.

Villa, B.R. \& L.E. Cockrum. 1962. Migration in the guano bat Tadarida brasiliensis mexicana (Saussure). J. Mammal. 43: 43-64.

Wilkins, K.T. 1989. Tadarida brasiliensis. Mamm. Species 331: 1-10.

Whitaker, J.O. 1993. Bats, Beetles, and Bugs. More big brown bats mean less agricultural pests... Bats 1: 23 .

Whitaker, J.O Jr., Ch. Neefus \& T. H. Kunz 1996. Dietary variation in the Mexican free-tailed bat (Tadarida brasiliensis mexicana). J. Mammal. 77: 716-724. 